\title{
Characterisation of the cancer-associated glucocorticoid system: key role of $11 \beta$-hydroxysteroid dehydrogenase type 2
}

Nicola Cirillo*,1, David J Morgan², Maria Carmela Pedicillo ${ }^{3}$, Antonio Celentano ${ }^{1}$, Lorenzo Lo Muzio ${ }^{3}$, Michael J McCullough ${ }^{1}$ and Stephen S Prime ${ }^{4}$

${ }^{1}$ Melbourne Dental School, The University of Melbourne, 720 Swanston Street, Carlton, Melbourne, VIC 3053, Australia; ${ }^{2}$ School of Cellular \& Molecular Medicine, University of Bristol, Bristol BS8 1TD, UK; ${ }^{3}$ Department of Clinical and Experimental Medicine, University of Foggia, Foggia 71122, Italy and ${ }^{4}$ Centre for Clinical and Diagnostic Oral Sciences, Institute of Dentistry, Barts and The London School of Medicine and Dentistry, Queen Mary University of London, London E1 2AD, UK

Background: Recent studies have shown that production of cortisol not only takes place in several non-adrenal peripheral tissues such as epithelial cells but, also, the local inter-conversion between cortisone and cortisol is regulated by the $11 \beta$-hydroxysteroid dehydrogenases (11 $\beta$-HSDs). However, little is known about the activity of this non-adrenal glucocorticoid system in cancers.

Methods: The presence of a functioning glucocorticoid system was assessed in human skin squamous cell carcinoma (SCC) and melanoma and further, in 16 epithelial cell lines from 8 different tissue types using ELISA, western blotting and immunofluorescence. $11 \beta$-HSD2 was inhibited both pharmacologically and by siRNA technology. Naïve $\mathrm{CD} 8^{+} \mathrm{T}$ cells were used to test the paracrine effects of cancer-derived cortisol on the immune system in vitro. Functional assays included cell-cell adhesion and cohesion in two- and three-dimensional models. Immunohistochemical data of 11 $\beta$-HSD expression were generated using tissue microarrays of 40 cases of human SCCs as well as a database featuring 315 cancer cases from 15 different tissues.

Results: We show that cortisol production is a common feature of malignant cells and has paracrine functions. Cortisol production correlated with the magnitude of glucocorticoid receptor (GR)-dependent inhibition of tumour-specific $\mathrm{CD}^{+}{ }^{+} \mathrm{T}$ cells in vitro. $11 \beta$-HSDs were detectable in human skin SCCs and melanoma. Analyses of publicly available protein expression data of $11 \beta$-HSDs demonstrated that $11 \beta$-HSD1 and -HSD2 were dysregulated in the majority (73\%) of malignancies. Pharmacological manipulation of $11 \beta$-HSD2 activity by $18 \beta$-glycyrrhetinic acid (GA) and silencing by specific siRNAs modulated the bioavailability of cortisol. Cortisol also acted in an autocrine manner and promoted cell invasion in vitro and cell-cell adhesion and cohesion in two- and three-dimensional models. Immunohistochemical analyses using tissue microarrays showed that expression of $11 \beta$-HSD2 was significantly reduced in human SCCs of the skin.

Conclusions: The results demonstrate evidence of a cancer-associated glucocorticoid system and show for the first time, the functional significance of cancer-derived cortisol in tumour progression.

Glucocorticoids (GC) are important lipid hormones that are involved in the regulation of stress responses, metabolism and immune homeostasis (Sapolsky et al, 2000). While the adrenal glands are the major source of GC, it is now recognised that GC synthesis occurs at other sites (Noti et al, 2009), such as the thymus (Vacchio et al, 1994), brain (MacKenzie et al, 2000; Davies and

*Correspondence: Professor N Cirillo; E-mail: nicola.cirillo@unimelb.edu.au

Received 16 November 2016; revised 11 April 2017; accepted 3 July 2017; published online 10 August 2017

(C) 2017 Cancer Research UK. All rights reserved 0007-0920/17 
MacKenzie, 2003), prostate gland (Herr and Pfitzenmaier, 2006), vascular endothelium (Takeda et al, 1994), intestinal epithelium (Sidler et al, 2011) and epidermis (Slominski and Wortsman, 2000; Hannen et al, 2011). In the skin, steroidogenesis is involved in the modulation of a variety of physiological functions (Slominski et al, 2000; Vukelic et al, 2011; Kennedy et al, 2015). Recently, we characterised the oral GC system in detail and showed that the local concentration of active cortisol in normal keratinocytes had the capacity to modulate disease progression in conditions where steroids are used routinely as a treatment modality (Cirillo and Prime, 2011; Cirillo et al, 2012). These findings raise the possibility that steroidogenesis may also play a key role in carcinogenesis, possibly through autocrine and paracrine mechanisms. Given the known immunomodulatory function of cortisol, we wished to examine whether local non-adrenal steroids had the capacity to modulate anti-cancer immune responses.

Regulation of neuroendocrine function occurs primarily through the control of the production and degradation of steroid hormones (Slominski and Wortsman, 2000). Activation of the steroid cortisone to cortisol occurs via $11 \beta$-hydroxysteroid dehydrogenase (HSD) 1 (HSD11B1 gene; Tomlinson et al, 2004) whereas the reverse, cortisol to cortisone, involves $11 \beta$-HSD2 (HSD11B2 gene; Ma et al, 2011). 11 $\beta$-HSDs, therefore, are key enzymes in the tissue-specific regulation of GC and current thinking suggests that their deregulation is associated with a variety of pathological processes in the skin (Hannen et al, 2011; Vukelic et al, 2011; Cirillo et al, 2012). While the role of $11 \beta$-HSD1 is well documented in epidermal physiology (Terao et al, 2011; Tiganescu et al, 2011; Itoi et al, 2013; Lee et al, 2013; Terao et al, 2014; Tiganescu et al, 2015), little is known about the role of $11 \beta$-HSD2 in skin keratinocytes. Clarification of the function of $11 \beta$-HSD2 in epidermal keratinocytes may have major clinical implications because of the therapeutic relevance of corticosteroid agents in the management of many skin disorders (Jackson et al, 2007).

In the present study, we assessed cortisol production in a broad spectrum of cell and tissue types. We show that cortisol levels correlated with inhibition of proliferation among tumour-specific $\mathrm{CD}^{+} \mathrm{T}$ lymphocytes. Using immunohistochemical analysis of cancer samples, we demonstrated alterations of $11 \beta$-HSD enzymes in a large number of tissue types, including skin squamous cell carcinoma (SCC). The role of $11 \beta$-HSD2 in normal and malignant keratinocytes was also investigated using functional assays of metabolism, adhesion and scattering from three-dimensional aggregates. The data demonstrate for the first time that $11 \beta$ HSD2 plays a key role in the pathophysiology of malignant epidermal cells.

\section{MATERIALS AND METHODS}

Antibodies and chemicals. Antibodies against residues 261-405 of human $11 \beta$-HSD2 (clone H-145), and amino acids $65-164$ of $11 \beta$-HSD1 (clone H-100), anti-tubulin, horseradish peroxidaseconjugated and FITC-conjugated anti-rabbit IgGs and $18 \beta$ glycyrrhetinic acid (18 $\beta$-GA) were obtained from Santa Cruz Biotechnology (Santa Cruz, CA, USA). Nitrocellulose membranes, keratinocyte growth medium and antibiotics/anti-mycotics were obtained from Invitrogen (Paisley, UK). Reagents for enhanced chemiluminescence and films were obtained from Amersham Biosciences (Buckinghamshire, UK) and the reagents for protein extraction and cell culture were obtained from Sigma (SigmaAldrich, Gillingham, Dorset, UK).

Cells and culture conditions. A broad spectrum $(n=16)$ of normal and malignant cell lines from eight different tissue types were used in this study including prostate (DU145, PC3, VCaP, LNCaP), bladder (T24, RT4), breast (MCF-7), colorectal (HT29,
SW620, SWH80), renal (mouse RenCA WT) and pancreas (HUpT3; a kind gift from Professor Chris Paraskeva, School of Cellular and Molecular Medicine, University of Bristol, UK). These cells were validated using karyotypic analysis prior to use. These cells retained their phenotype and function, together with their growth characteristics in vitro, throughout the 3 months that they were routinely kept in continuous culture. HaCaT cells are a strain of immortalised human skin keratinocytes that have an active steroid metabolism (Cirillo and Prime, 2011) and display normal differentiation in vivo (Boukamp et al, 1988; Milewich et al, 1988). HaCaT c-Ha-ras-transfected clones (I-7, II-3, and RT-3; Fusenig and Boukamp, 1998) were kind gifts from Professor Norbert Fusenig (DKFZ, Heidelberg, Germany). Following subcutaneous transplantation to athymic mice, HaCaT cells are nontumourigenic, I-7 cells form non-invasive epidermoid cysts, II-3 cells form primary SCCs with minimal metastatic dissemination and RT-3 cells, the most aggressive cell type, form large SCCs at the site of inoculation and have widespread metastatic dissemination (Fusening and Boukamp, 1998). The cells are widely used as a model of epidermal cancer progression (Davies et al, 2006) and were last authenticated prior to commencing the experiments in 2012 with mRNA microarrays. The oral SCC cell strain (H357) underwent full genome sequencing in 2016 whereas the skin SCC cell line A431 was purchased from Sigma-Aldrich.

All of the cell lines/strains were derived prior to 2001 and, therefore, were not subject to Ethical Committee approval in the UK. The cells were placed in serum-free DMEM/F12 for $24 \mathrm{~h}$ before the collection of supernatants for cortisol assessment; RT-3 was cultured in media containing $400 \mathrm{mg} \mathrm{ml}^{-1}$ geneticin sulphate (G418; PAA laboratories, Leeds, UK). At the time of experimentation, cells were seeded in 35- $\mathrm{mm}$ Petri plastic dishes and grown to confluence. Cells were grown in a humidified atmosphere of $5 \%$ $\mathrm{CO}_{2}$ /air at $37^{\circ} \mathrm{C}$. Ethics committee approvals were obtained for this study both in Bristol (E5133) and in Melbourne (1340716.1), and high standards of ethics were applied in carrying out all of the investigations.

Multicellular aggregates (MCAs) were prepared according to published protocols (Kantak and Kramer, 1998). To generate MCAs, cell monolayers were first treated with EDTA to prepare single cell suspensions and then, the cells were seeded onto polyhydroxylethyl-methacrylate (poly-HEMA)-coated 60-mm dishes $\left(6 \times 10^{5}\right.$ cells per dish) in the presence of serum-free DMEM for $12 \mathrm{~h}$, with or without $0.5 \%$ (w/v) $18 \beta$-GA. Unlike malignant keratinocytes (Kantak and Kramer, 1998), the culture of normal keratinocytes for prolonged periods (e.g. $24 \mathrm{~h}$ ) in the absence of extracellular cell matrixattachment resulted in significant cell death and non-viable MCAs (data not shown).

Tumour-specific $\mathrm{CD8}^{+} \quad \mathrm{T}$ lymphocyte proliferation in vitro. Using anti-CD8 MACS midiMACS (Miltenyi Biotec, Bisley, UK), single-cell suspensions of peripheral lymph node and spleen cells from CL4 TcR-transgenic mice were enriched for naïve $\mathrm{CD}^{+} \mathrm{T}$ lymphocytes that recognised a tumour-specific antigen (Jenkinson et al, 2005). Anti-CD3 monoclonal antibody $\left(10 \mu \mathrm{g} \mathrm{ml}^{-1}\right)$ was added to triplicate wells of 96-well rounded plates in a total volume of $50 \mu \mathrm{l} 1 \times \mathrm{PBS}$ and incubated in a $5 \%$ vol./vol. $\mathrm{CO}_{2}$ humidified atmosphere at $37^{\circ} \mathrm{C}$ for $1.5 \mathrm{~h}$; control wells contained $1 \times$ PBS only. Plates were washed three times with $300 \mu \mathrm{l} 1 \times$ PBS. In certain experiments, cortisol (10$1000 \mathrm{ng} \mathrm{ml}^{-1}$ ) was added to the wells. $5 \times 10^{4}$ purified naïve, $\mathrm{CL} 4, \mathrm{CD}^{+}{ }^{+} \mathrm{T}$ lymphocytes were added to each well and were cultured in a $5 \%$ vol./vol. $\mathrm{CO}_{2}$ humidified atmosphere at $37^{\circ} \mathrm{C}$ for $72 \mathrm{~h}$ and pulsed with $1 \mu \mathrm{Ci}$ per well ${ }^{3} \mathrm{H}$-thymidine (Amersham BioSciences, Buckinghamshire, UK) in $25 \mu \mathrm{l}$ serum-free culture media for the last $8 \mathrm{~h}$. Cells were harvested on fibre filters (Filtermats; COX Scientific Ltd., Kettering, UK) using a 24-well harvester (Skatron, Flow Laboratories, Oslo, Norway). Fibre filters 
were then dried and sealed into bags with $3 \mathrm{ml}$ Betaplate Scint (Wallac Oy, Turku, Finland). ${ }^{3} \mathrm{H}$-thymidine incorporation was read by a 1450 Microbeta liquid scintillation counter for windows 2.7 (Wallac Oy). Data were analysed using Microsoft Office Excel and Prism 4.03 software (Graphpad).

siRNA transfection experiments. $11 \beta$-HSD-directed siRNA pools and the negative-control pool were transfected as described previously (Cirillo and Prime, 2011). The efficiency of transfection was monitored by western blotting (WB) of $11 \beta$-HSD $1 / 2$ expression.

Western blotting. For the assessment of protein levels, WB on whole-cell lysates and in-cell WB on culture monolayers was undertaken using standard procedures (Cirillo et al, 2010). For all $\mathrm{WB}$, a 1:500 dilution was used for the primary antibodies and the species-specific secondary IgG was diluted to $1: 5000$.

Enzyme-linked immunosorbent assay. For quantification of cortisol levels with conventional enzyme-linked immunosorbent assay (ELISA), the conditioned media were collected at time points specified in the Results. Cortisol concentrations were measured with a Cortisol Parameter Assay Kit (R\&D Systems, Minneapolis, MN, USA) and quantified at $415 \mathrm{~nm}$ with the ELx808 Microplate Reader (BioTek Instruments, Inc., Winooski, VT, USA).

Immunohistochemistry. Skin tissue microarrays (Cat. No. SK483, multiple skin SCC tissue arrays; US Biomax, Rockville, MD, USA) and formalin-fixed, paraffin-embedded skin biopsies from individuals with SCC, melanoma, and without skin disease were subjected to immunohistochemical analyses, as described previously (Ricketts et al, 1998; Lanza et al, 2008). Following antigen retrieval, the primary antibody to $11 \beta$-HSD 1 and $11 \beta$-HSD2 was used at a $1: 100$ and 1:50 dilution, respectively, and the speciesspecific secondary IgG was diluted to $1: 5000$. The primary antibody was withheld from negative controls and these were incubated in diluent alone. Staining was quantified following the criteria detailed by Yao et al (2007). Normal and tumour sections were scored independently by two investigators (SSP and NC) and graded as no (0), weak (1), moderate (2), or strong (3) staining.

Database search. A publicly available repository (http://www.proteinatlas.org) was used to access immunohistochemical data of $11 \beta$-HSDs staining, as reported in Supplementary Table 1. GENT (http://medicalgenome.kribb.re.kr/GENT), a Gene Expression across Normal and Tumour tissue database, was used to interrogate mRNA expression in both cell lines and tissues.

Immunofluorescence microscopy. Immunofluorescence microscopy was performed as previously described (Cirillo et al, 2007), but with minor modifications. Briefly, cells were cultured in four-well-plates (Nunc Cell-Culture Treated Multidishes, Thermo Fisher Scientific, Paisley, UK; Fisher Scientific UK Ltd, Loughborough, UK) in standard conditions. At $60 \%$ confluence, cells were fixed with $100 \%$ vol./vol. ice-cold methanol for $10 \mathrm{~min}$ at $4{ }^{\circ} \mathrm{C}$ and then incubated with $0.5 \mu \mathrm{g} \mathrm{ml}^{-1}$ Hoetstch staining (H6024, SigmaAldrich) for $30 \mathrm{~min}$ at $4{ }^{\circ} \mathrm{C}$ and then blocked with $5 \% \mathrm{wt} / \mathrm{vol}$. BSAPBS solution at $4{ }^{\circ} \mathrm{C}$ for $60 \mathrm{~min}$. Samples were incubated overnight at $4{ }^{\circ} \mathrm{C}$ with anti- $11 \beta$-HSD $1 / 2$ primary antibody at $1 / 100$ dilution in $2 \% \mathrm{wt} / \mathrm{vol}$ BSA-PBS followed by FITC-conjugated speciesspecific IgG for $1 \mathrm{~h}$ at $1 / 1000$ dilution in $2 \% \mathrm{wt} / \mathrm{vol}$. BSA-PBS. All intermediate washing steps were performed with PBS. Images were taken with a fluorescence microscope (EVOS FLoid Cell Imaging Station, Life Technologies, Cramlington, UK).

Adhesion and cohesion assays in two- and three-dimensional models. To quantify the strength of $2 \mathrm{D}$ cell-to-cell adhesion in monolayers, we undertook dispase-based cell dissociation assays, as described previously (Calautti et al, 1998).
For 3D cohesion assays, MCAs were first analysed by phasecontrast microscopy to check for their compact appearance. Then, the MCAs were sedimented in $15 \mathrm{ml}$ tubes and subjected to mechanical stress by pipetting 20 times with a $5 \mathrm{ml}$ pipette. The residual spheroids were sedimented at $1 G$ and the ratio of the number of MCA-forming cells and the number of single cells in suspension was calculated. The ratio of total to single cells was indicative of intercellular adhesive strength (Cirillo and Boutros, 2008).

For scattering assays, the surface (pixels) covered by cells originating from disaggregating MCAs were measured and then those values were normalised against the total number of cells.

Statistical analysis. The statistical significance of the data was evaluated by the Student's $t$-test. Data are reported as mean \pm standard deviation and differences were considered to be significant when $p$ was $<0.05$.

\section{RESULTS}

Tumour-derived cortisol inhibits lymphocyte proliferation. We and others have shown that tumour-specific $\mathrm{CD} 8^{+} \mathrm{T}$ lymphocyte activity is suppressed by factors produced within the tumour microenvironment (Ahmadi et al, 2008; Janicki et al, 2008; Basingab et al, 2016). To test whether the production of cortisol by tumour cells had paracrine effects that could target tumourspecific immune responses, we exposed naïve tumour-specific $\mathrm{CD}^{+} \mathrm{T}$ lymphocytes (CL4 cells) to conditioned media from cortisol-producing II-3 malignant epidermal cells (Cirillo et al, 2012; Kennedy et al, 2015) stimulated with ACTH and, in parallel, treated lymphocytes with hydrocortisone. The data showed that the rate of proliferation of $\mathrm{CL} 4 \mathrm{CD}^{+} \mathrm{T}$ lymphocytes was significantly reduced in the presence of conditioned media from ACTH-stimulated II-3 cells; the effect was inhibited in the presence of the glucocorticoid receptor (GR) inhibitor RU486 thereby confirming that such inhibition was specific to cortisol (Figure 1A). In control experiments we confirmed that hydrocortisone directly inhibited the rate of proliferation among naïve mouse tumourspecific $\mathrm{CD}^{+}{ }^{+} \mathrm{T}$ cells primed in vitro using plate-bound anti-CD3 and anti CD28 mAb in a dose-dependent manner (Supplementary Figure 1). We extended these observations to examine whether unstimulated malignant cells from other tissue-types synthesised cortisol de novo and, if so, whether conditioned media from these same cells could inhibit naïve tumour-specific $\mathrm{CD} 8^{+} \mathrm{T}$ lymphocyte proliferation. All (12 out of 12) of the malignant cell lines from the prostate, bladder, breast, colorectum, kidney and pancreas (Supplementary Figure 2A) produced detectable levels of cortisol $\left(0.1-8.4 \mathrm{ng} \mathrm{ml}^{-1}\right)$ at baseline; 11 of 12 reduced the proliferation rate of $\mathrm{CD}^{+} \mathrm{T}$ lymphocytes and one cell line from bladder cancer (T24) increased the proliferation (Supplementary Figure 1). Cell lines of colorectal origin (HT29, SW620, SWH80) produced little, if any, cortisol but caused marked inhibition of proliferation (Figure 1B) suggesting that there may be other mechanisms of immune suppression/regulation exhibited by this cell type (see Discussion). When the data relating to the colorectal lines were excluded, there was a strong correlation between basal cortisol production and inhibition of lymphocyte proliferation (Spearman's correlation coefficient was 0.89 ; Figure 1C). Collectively, the data demonstrate that a large variety of cancer cells from different tissues produce active cortisol and inhibit tumour-specific CD ${ }^{+} \mathrm{T}$ lymphocyte proliferation in vitro.

Cortisol interconversion is modulated by $11 \beta$-hydroxysteroid dehydrogenases. The above experiments demonstrated that the production of basal levels of cortisol was common in tumour cells. Next, we wanted to test whether the interconversion of cortisol could be modulated locally and, to this end, we used HaCaT skin 


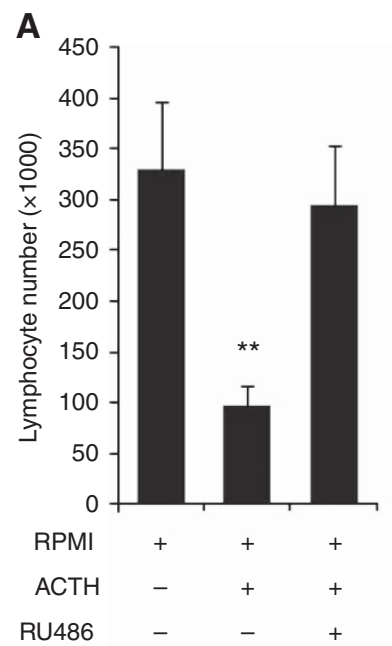

C

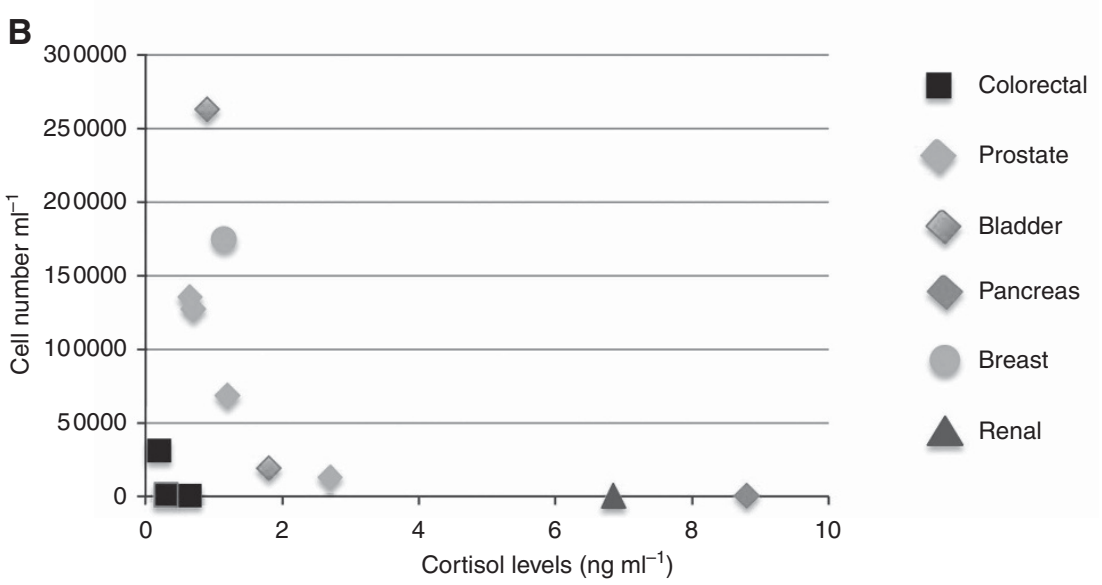

Figure 1. Naïve TcR transgenic tumour antigen-specific CL4 CD8 ${ }^{+}$T lymphocytes were incubated for $24 \mathrm{~h}$ with supernatants of ACTH-treated II-3 cells in the presence of the GR inhibitor RU486, or without treatment (A). CD8 ${ }^{+}$lymphocytes were incubated with supernatants from 12 cancer cells with known basal cortisol production. The cells were counted after $24 \mathrm{~h}$ and their number was plotted against the corresponding cortisol levels in the supernatants $(\mathbf{B}, \mathbf{C}) .{ }^{\star \star} P<0.01$. A full colour version of this figure is available at the British Journal of Cancer journal online.

keratinocytes and their mutant c-Ha-ras-transfected clones (Figure 1A). All clones consistently secreted cortisol under basal conditions and increased steroid production following stimulation with ACTH; c-Ha-ras-transfected clones that formed malignant SCCs following transplantation to athymic mice (II-3, RT-3) produced significantly more cortisol following ACTH stimulation than their non-tumourigenic counterparts (HaCaT) and c-Ha-ras-transfected clones that formed benign epidermoid cysts on transplantation to athymic mice (I-7). Other SCC cells derived from tumour samples were also investigated and were found to secrete cortisol under basal conditions (Supplementary Figure 3).

Previous studies demonstrated that $\mathrm{HaCaT}$ expressed active $11 \beta$-HSD1 and $11 \beta$-HSD2 enzymes (Cirillo and Prime, 2011; Kennedy et al, 2015). In this study, we extended these observations and demonstrated that benign (I-7) and malignant (II-3, RT-3) c-Ha-ras clones also expressed functional $11 \beta$-HSD1 and $11 \beta$ HSD2 (Figures $2 \mathrm{~B}-\mathrm{D}$ ). Silencing of $11 \beta$-HSD1 correlated with a reduced ability of malignant cells to convert cortisone to active cortisol; this was progressively restored by an increase of $11 \beta$ HSD1 expression (Figure 2C). Similarly, 11 $\beta$-HSD2 controlled the inactivation of cortisol in a dose-dependent fashion (Figure 2D). $11 \beta$-HSD1 and $11 \beta$-HSD2 were also expressed in SCCs $(n=10)$ and melanomas $(n=10)$ (Figures $2 \mathrm{E}$ and $\mathrm{F}$ ). Taken together, the data demonstrate that skin cancer cells have the capacity to regulate cortisol levels through the expression of $11 \beta$-HSD1 and $11 \beta$-HSD2.
Expression of $11 \beta$-HSD enzymes is altered in cancers. To investigate whether the enzymes modulating the local concentration of active steroid were dysregulated in malignancy, we examined the expression of $11 \beta$-HSD $1 / 2$ in normal and malignant tissues using publicly available data sets. According to GENT data sets, mRNA levels encoding for $11 \beta$-HSD1 (HSD11B1) and $11 \beta$ HSD2 (HSD11B2) differed in normal and neoplastic tissues. Therefore, we examined the expression profile of these enzymes at the protein level using Protein Atlas (http://www.proteinatlas.org). Fifteen normal tissue types $(n=126$; controls) were matched with their malignant counterparts $(n=315$; cancers); a total of 441 different samples were examined in which there were 590 cancer specimens (Supplementary Table 1). Twelve of $15(80 \%)$ cancer types had significant changes $(P<0.05)$ of $11 \beta$-HSDs staining (Figure 3 ). In the main, there was an inverse relationship in the pattern of expression of $11 \beta$-HSD1 and $11 \beta$-HSD2, with either an increase in $11 \beta$-HSD1 staining (cervical, glial, urotelial) or decreased expression of $11 \beta$-HSD 2 (colon, lung, stomach, thyroid), or both (endometrial, head and neck, renal, prostate). 11 $\beta$-HSD1 was also upregulated in liver cancer with a $p$-value close to significance $(50 \%$ overall increase compared to control tissue, $P=0.069)$. Exceptions to the above generalisation included breast and pancreatic cancers which did not show major changes compared to matched normal tissues and cancer of the testis which showed increased $11 \beta$-HSD2 levels. Collectively, these results strongly suggest that dysregulation of the enzymes 
A

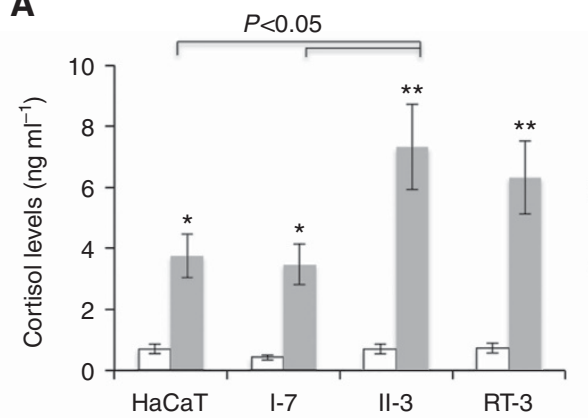

C
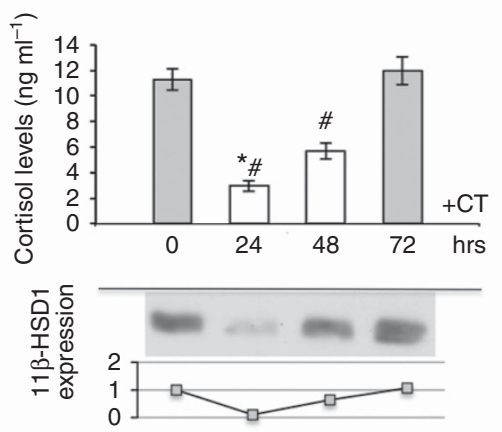

B

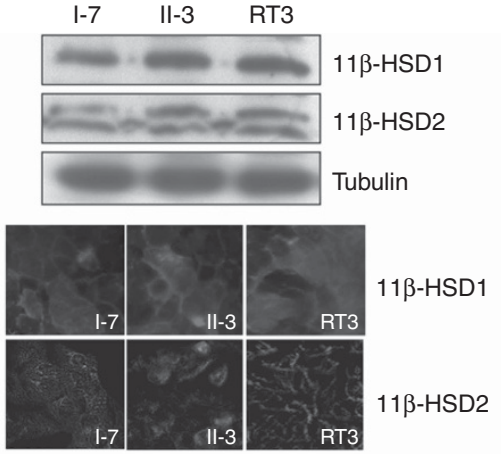

D

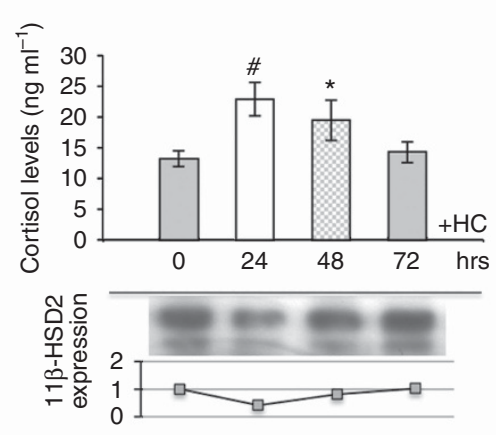

E

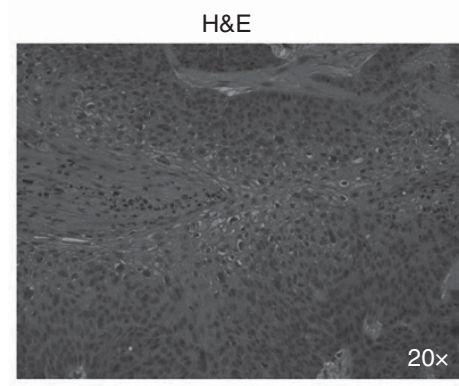

$\mathbf{F}$

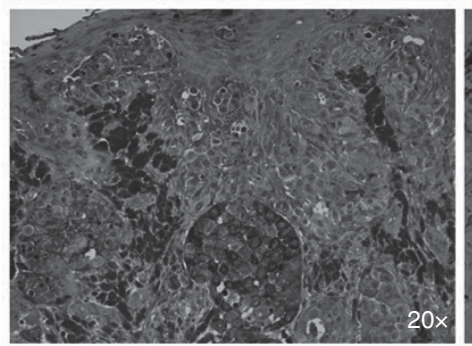

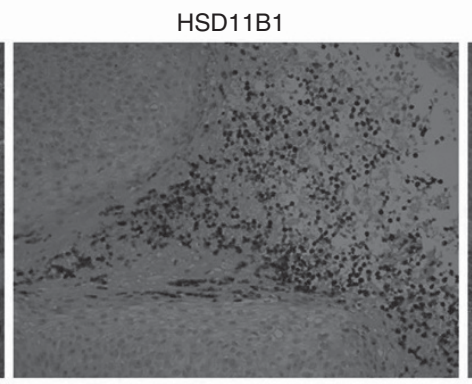
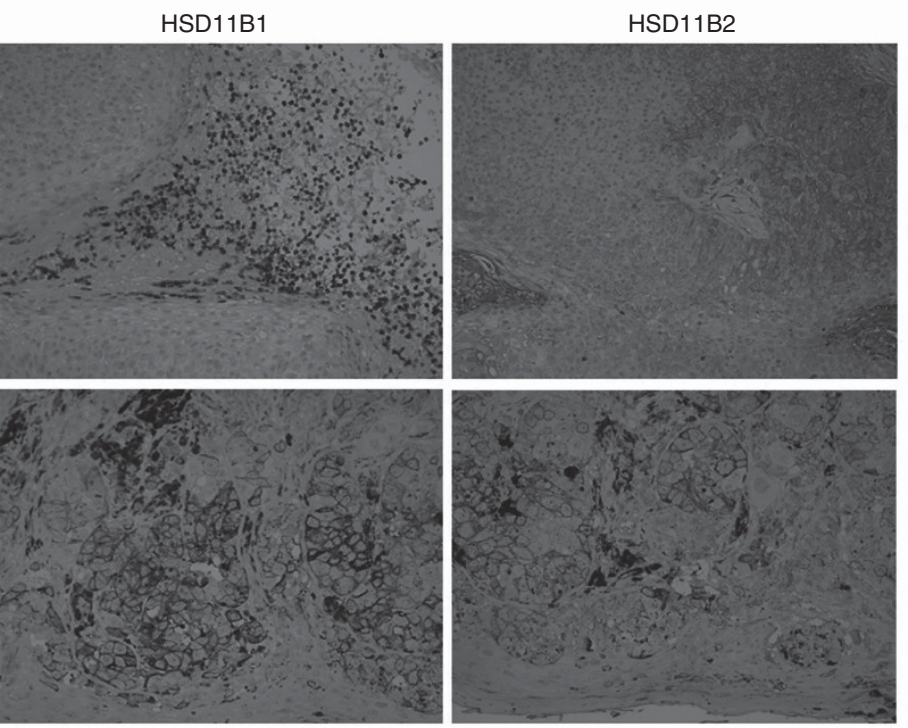

Figure 2. Cortisol levels in the supernatant of un-stimulated cells (Bsl) and cells treated with $10 \mathrm{~nm} \mathrm{ACTH} \mathrm{for} 24 \mathrm{~h}$ (ACTH) were assessed by ELISA (A). Western blotting and immunofluorescence were undertaken to investigate the expression of $11 \beta$-HSD1 and $11 \beta$-HSD2 proteins (B). siRNA was used to transiently knockdown the expression of $11 \beta$-HSD1 (C) and 11 $\beta$-HSD2 (D) in II-3 cells; in parallel, the protein level of these enzymes was assessed by western blotting. Silencing of $11 \beta$-HSD1 resulted in a reduced ability of II-3 to activate cortisone (100 nM) into cortisol (C). Silencing of $11 \beta$-HSD2 in HC-treated cells (100 nM) resulted in an increase in the concentration of active cortisol in supernatants (D). Both effects were transient and progressively reverted when the expression levels of $11 \beta$-HSDs were restored. Both enzymes were detectable by IHC in human skin cancers, namely SCC (E) and melanoma (F). ${ }^{*} P<0.05,{ }^{\star \star} P<0.01,{ }^{\#} P<0.005,{ }^{*} P<0.001$. A full colour version of this figure is available at the British Journal of Cancer journal online.

associated with local cortisol interconversion is a common feature of solid tumours.

Local cortisol levels regulate keratinocyte invasion, cohesion and scattering in a two- and three-dimensional models of epidermal cancer. We hypothesised that the local production and degradation of cortisol could influence tumour progression. First, we demonstrated that cortisone, cortisol (hydrocortisone when used as a medication) and ACTH acted directly to increase the invasion of epidermal keratinocytes (Figures 4A-D). The effect was most striking among II-3 cells where there was a statistical increase in invasion following treatment with hydrocortisone and ACTH. The effect was not seen in HaCaT, I-7 or RT-3 cells.

Hydrocortisone has been shown to exert pro-adhesive effects in normal keratinocytes (Nguyen et al, 2004). As inhibition of $11 \beta$ HSD2 leads to increased cortisol levels in the culture medium, a dispase-based assay was undertaken to investigate whether inhibition of $11 \beta$-HSD2 altered intercellular adhesion in malignant 


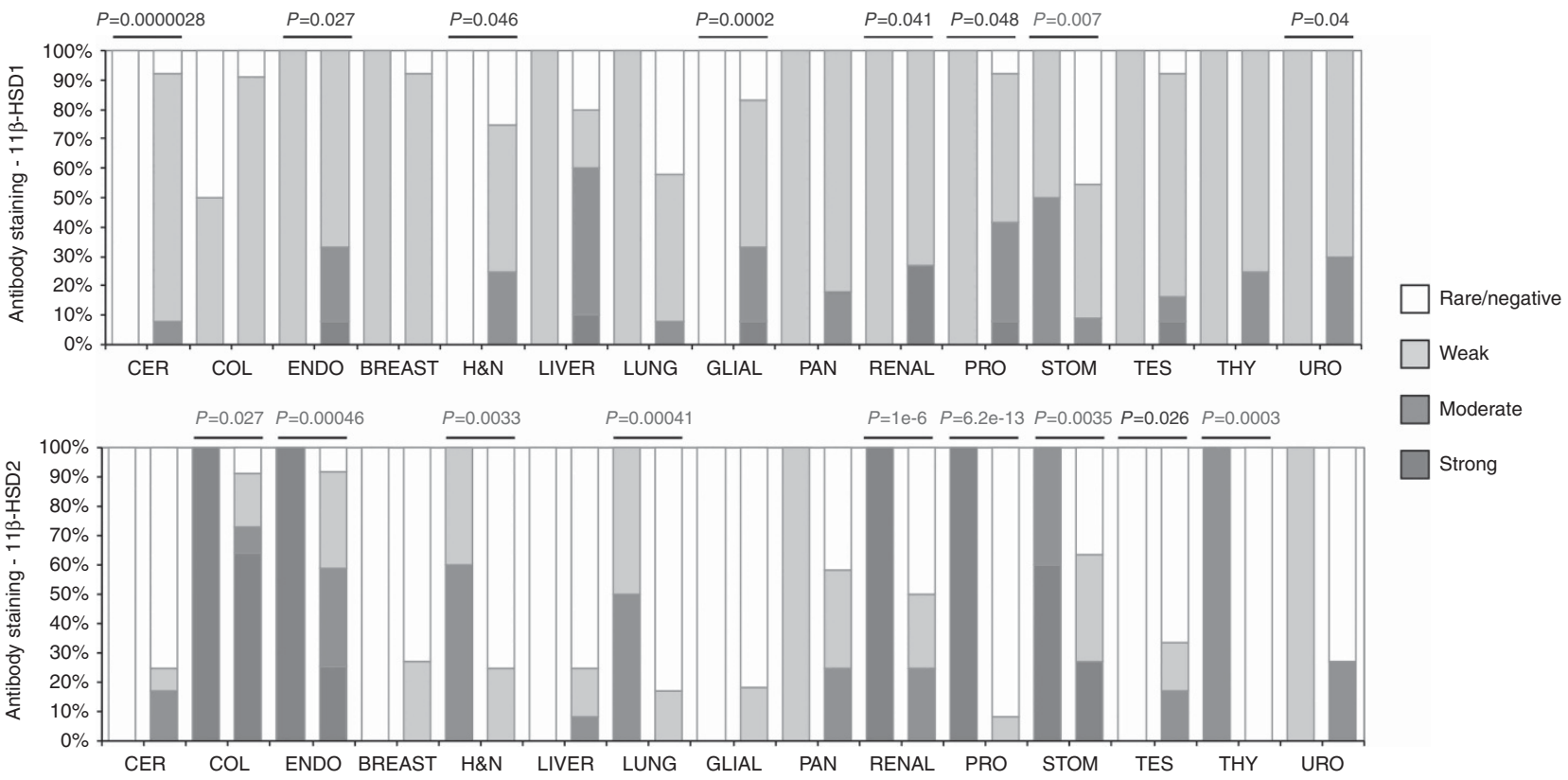

Figure 3. Staining intensity of $11 \beta$-HSD1/2 using a publicly available data set featuring 15 different normal/malignant tissues was computed and illustrated by histogram. P-value of paired t-test is reported. Blue colour indicates upregulation whereas red colour indicates downregulation. A full colour version of this figure is available at the British Journal of Cancer journal online.

A

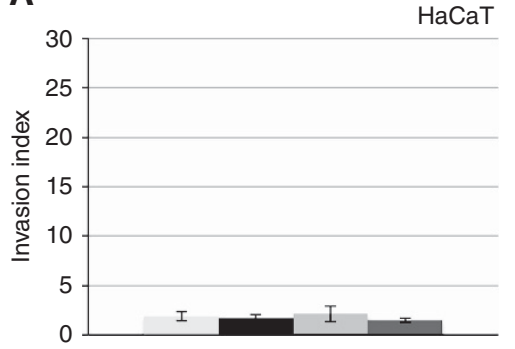

C

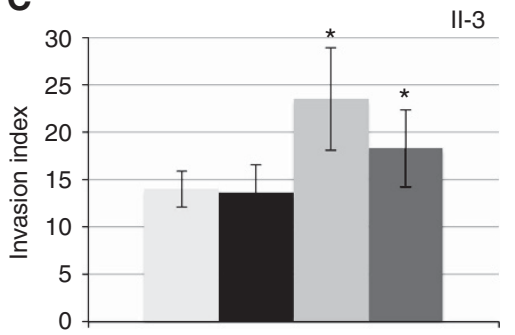

B

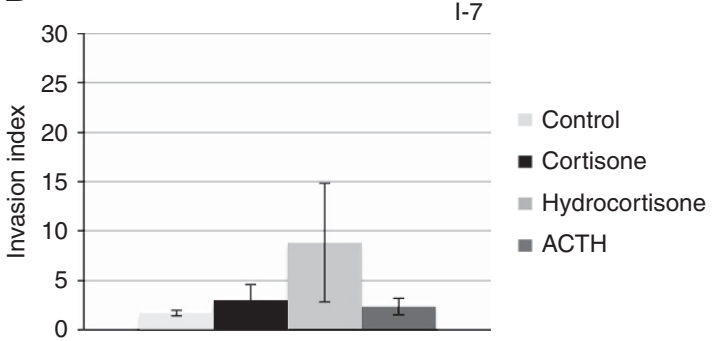

D

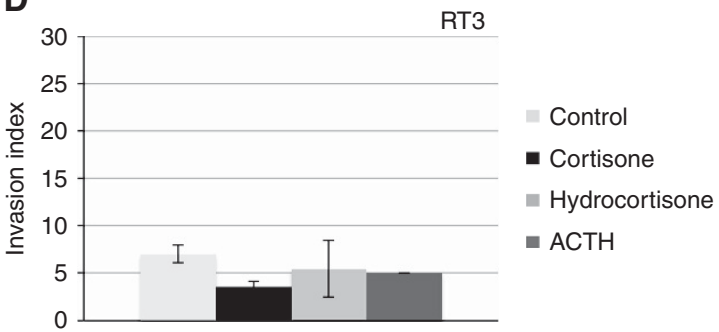

Figure 4. HaCaT (A), I-7 (B), II-3 (C) and RT-3 (D) were used for the invasion assay in the presence of 100 nm cortisone, $100 \mathrm{~nm}$ hydrocortisone, $10 \mathrm{~nm}$ ACTH or without treatment (Control). ANOVA statistical analysis was used to determine the significance of the results. The histograms show mean values of four independent experiments \pm standard deviation. ${ }^{\star} P<0.05$.

epidermal cells. For this experiment we opted for a pharmacological block of the enzyme using $18 \beta$-GA because this inhibitor, unlike siRNAs, allowed achieving consistent levels of $11 \beta$-HSD2 activity throughout the experimental period (not shown). As shown in Figures $5 \mathrm{~A}-\mathrm{C}$, keratinocyte monolayers displayed increased cell-cell adhesive strength (i.e., resistance to cell-cell detachment) in the presence of the $11 \beta$-HSD2 inhibitor $18 \beta$-GA. $11 \beta$-HSD2 activity was also examined in a three-dimensional model of cell adhesion. Multicellular aggregates were prepared in the presence or absence of $18 \beta$-GA (Figures $5 \mathrm{D}$ and $\mathrm{E}$ ) and while the number of cells that aggregated together in suspension and formed MCAs after $24 \mathrm{~h}$ of incubation was similar in both groups (not shown), intercellular cohesion of mature (24h) MCAs, as quantified by the release of single cells from the spheroids after mechanical stress, was higher in MCAs cultured in the presence of $18 \beta$-GA (Figure 5H). The MCAs were left to attach and disaggregate on a collagen substrate in $18 \beta$-GA-free medium and migration from the core of the cell aggregate was measured in a scattering assay. Control MCAs were almost entirely dissolved $6 \mathrm{~h}$ after seeding (Figure 5F) whereas MCAs grown in the presence of $18 \beta$-GA displayed a reduced ability to scatter and migrate from the spheroids after attachment on collagen substrates (Figure 5G) and were able to cover only $\sim 55 \%$ of the area compared to control MCAs (Figure 5I).

Taken together, the data demonstrate that pharmacological modulation of cortisol degradation via $11 \beta$-HSD2 inhibition influences cell adhesion and three-dimensional intercellular cohesion of malignant keratinocytes. 
A

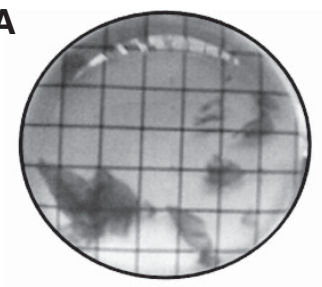

B

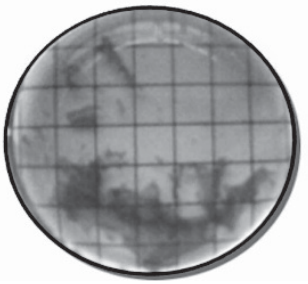

C

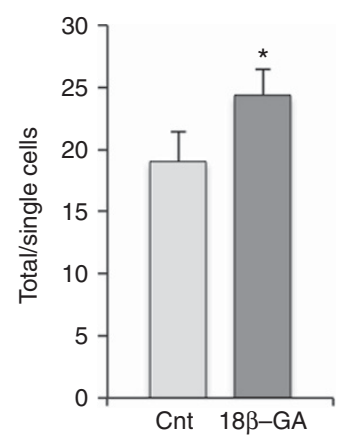

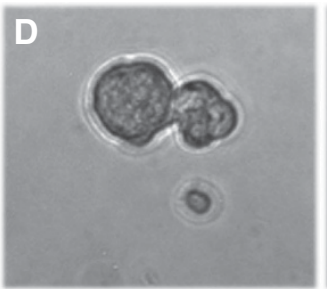
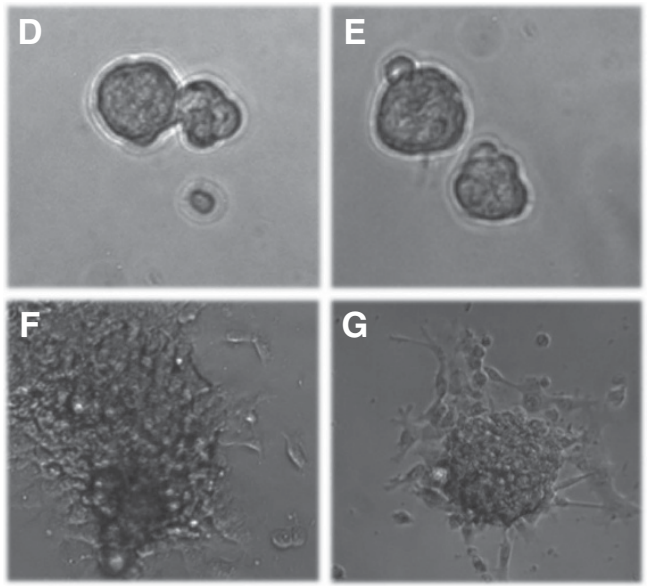

H

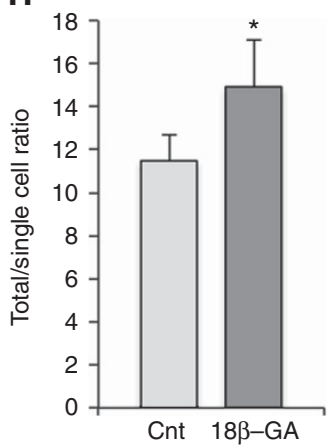

I

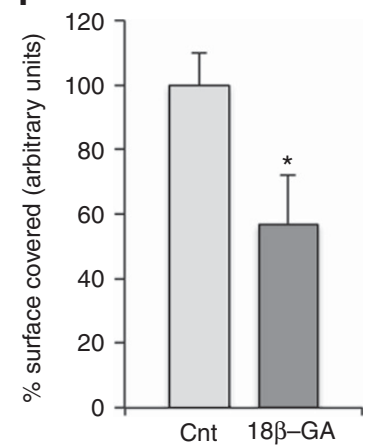

Figure 5. A dispase-based assay was undertaken to assess cell-cell adhesion strength in II-3 cells with or without treatment with $18 \beta$-glycyrrhetinic acid $(\mathbf{A}-\mathbf{C})$. Cohesion strength $(\mathbf{D}, \mathbf{E}, \mathbf{H})$ and scattering $(\mathbf{F}, \mathbf{G}, \mathbf{I})$ of $3 \mathrm{D}$ cellular aggregates in the presence or absence of $18 \beta$-GA was also assessed. ${ }^{\star} P<0.05$. A full colour version of this figure is available at the British Journal of Cancer journal online.
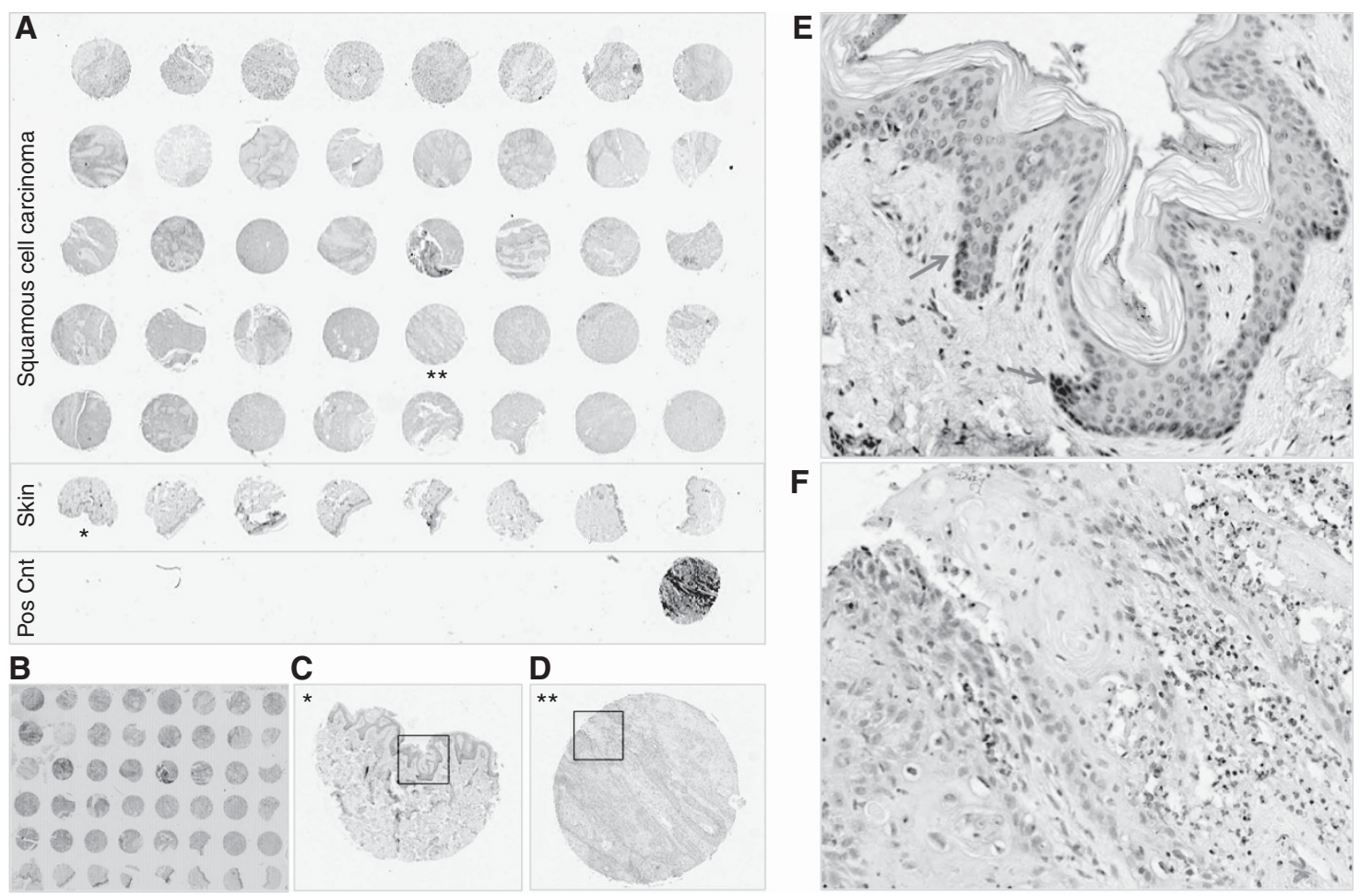

Figure 6. Staining of $11 \beta$-HSD2 at a $1: 100$ dilution was undertaken using tissue microarrays. The array is shown with (A) and without (B) IHC staining and shows cases of squamous cell carcinoma $(n=40)$, normal skin tissues $(n=8)$ and a positive control (melanoma). Typical aspects of normal $(\mathbf{C}, \mathbf{E})$ and cancerous $(\mathbf{D}, \mathbf{F})$ samples are reported at $\times 4$ and $\times 20$ magnification. ${ }^{*} P<0.05, * \star P<0.01$. A full colour version of this figure is available at the British Journal of Cancer journal online. 
Expression of $11 \beta$-HSD2 in skin and its downregulation in squamous cell carcinoma. The above results suggested that $11 \beta$-HSD2 expression was important to the bioavailability of tumour-derived cortisol. However, previous research on the expression of $11 \beta$-HSD 2 in the human integument has given conflicting results (Tiganescu et al, 2011; Vukelic et al, 2011; Terao et al, 2013). In this study, we used a rabbit antibody against the residues 261-405 of human $11 \beta$-HSD2 at a $1: 100$ dilution, a concentration at which normal skin displayed strong staining (Supplementary Figure 4). Using tissue arrays, immunohistochemical expression of $11 \beta$-HSD2 was examined in 40 cases of SCC and 8 normal skin controls (Figure 6). The intensity of $11 \beta$-HSD2 staining in the malignant tissues was consistently less than control tissues. Eleven of 40 SCCs (27.5\%) displayed no staining while staining intensity was weak to moderate in a further 25 samples $(62.5 \%)$. Overall, the $11 \beta$-HSD2 staining score in SCC was statistically less $(P<0.05)$ than in the controls (Supplementary Figure 5). We therefore conclude that the expression of $11 \beta$-HSD2, a key enzyme in the local control of keratinocyte-derived cortisol, is significantly reduced in SCCs of the skin.

Taken together, the data demonstrate that cancer cells produce cortisol irrespective of their tissue of origin. Furthermore, $11 \beta$ HSD2-mediated regulation of tumour-derived cortisol potentially plays an important role in the pathobiology of epidermal malignancy.

\section{DISCUSSION}

This study presents a series of observations that demonstrate an important role for the GC system, and specifically for $11 \beta$-HSD2, in the physiology of normal and malignant epithelial cells. First, we show that cortisol production is a common feature of a broad spectrum of cancers and that cancer-derived cortisol inhibits $\mathrm{CD}^{+}$cytotoxic $\mathrm{T}$ lymphocyte proliferation in a GR-specific fashion. Second, we demonstrate that $11 \beta$-HSD1/2 expression is altered in many different cancer types in a fashion that is predicted to lead to a pro-cortisol-producing phenotype. Third, we establish that normal human skin tissues express detectable levels of $11 \beta$ HSD2 and that levels are reduced in SCCs. Fourth, we demonstrate in vitro that $11 \beta$-HSD2 is synthesised by human malignant keratinocytes under basal conditions and its expression and activity regulate both the production and inter-conversion of active cortisol. Finally, we show that $11 \beta$-HSD2 modulates intercellular adhesion and that inhibition of $11 \beta$-HSD 2 by $18 \beta$-GA increases intercellular cohesion.

A major finding of this study was that cancer cells produce cortisol regardless of their tissue of origin, strongly supporting the view that a cancer-associated GC system is active in malignancy. Not only was cortisol production enhanced by ACTH treatment but also, analysis of $\mathrm{CD} 8^{+} \mathrm{T}$ cell responses revealed a linear correlation between basal cortisol levels in supernatants from cancer cells and inhibition of lymphocyte proliferation. Given the importance of T-cell-mediated responses in the progression of cancer, as well as its prognostic relevance (Knutson and Disis, 2005; Ward et al, 2014), our data suggest that the production of cortisol by malignant cells may have an important immunoregulatory function. These findings are consistent with Sidler et al (2011) who showed that tumour-derived GCs from colon cancer induced suppression of T-cell activation. The present study, however, is the first to extend this concept to a broad spectrum of solid tumours. It is also intriguing that under our experimental conditions, colorectal cancer cells (HT29, SW620, SWH80) were the only cell type not to show a correlation between cortisol production and inhibition of CD8 T lymphocytes. Specifically, these cells produced low amounts of basal cortisol but concurrently reduced T-cell proliferation. We have shown previously that other tumour-derived molecules such as prostaglandins may be involved in the immune regulation of CD8 cells in cancer (Ahmadi et al, 2008; Basingab et al, 2016).

In the past two decades, the intracellular inter-conversion of inactive and active steroids by the $11 \beta$-HSDs has emerged as a key mechanism underlying tissue-specific regulation of GC action. In non-adrenal tissues, $11 \beta$-HSDs have been shown to play a crucial role in the control of basic physiological functions, as well as in disease processes such as osteoporosis (Cooper, 2008), insulinresistance (Purnell et al, 2009), chronic periodontitis (Nakata et al, 2016) and cancer (Rabbitt et al, 2003; Zhang et al, 2009). With regard to squamous epithelia, a number of studies from Slominski's group have supported the hypothesis that the skin has the potential to act as a neuroendocrine organ (Slominski et al, 2006, 2007, 2011). We have extended these observations and demonstrated that squamous epithelium lining the oral cavity acts as a corticosteroid-producing system and that alteration of $11 \beta$-HSDs in oral keratinocytes may play an important role in disease (Cirillo et al, 2012). However, while studies addressing the function of $11 \beta$ HSDs in epidermal tissues support a key role for $11 \beta$-HSD type 1 in epidermal biology and pathophysiology (Hardy et al, 2006; Hennebert et al, 2007; Terao et al, 2011; Tiganescu et al, 2011; Itoi et al, 2013; Lee et al, 2013; Terao et al, 2014; Tiganescu et al, 2015), there is some disagreement about the putative expression and function of $11 \beta$-HSD type 2 (Cirillo and Prime, 2011; Tiganescu et al, 2011; Vukelic et al, 2011; Terao et al, 2013). In the reports by Tiganescu et al (2011) and Terao et al (2013), for example, the expression of $11 \beta$-HSD 2 could not be demonstrated in human skin suggesting that keratinocytes cannot de-activate cortisol. In the present study, we demonstrated $11 \beta$-HSD2 in normal skin specimens, findings that are consistent with our published data showing $11 \beta$-HSD2 at both the mRNA and protein levels in keratinocytes. We conclude that $11 \beta$-HSD2 is present in epidermal keratinocytes.

To the best of our knowledge, the data reported in the present study are the first to show that $11 \beta$-HSD 2 is not only expressed by epidermal keratinocytes but, also, that the pharmacological manipulation of $11 \beta$-HSD2 modulates cortisol levels and regulates certain cellular functions. The question remains, however, as to whether $11 \beta$-HSD2 can be modified for therapeutic benefit. Interestingly, it has been shown recently that $18 \beta$-GA, administered either prophylactically or therapeutically, induces a dramatic reduction in bone loss using a mouse model of periodontitis (Sasaki et al, 2010). The authors suggested that this effect was independent of GC because a downregulation of $11 \beta$-HSD2 mRNA was not seen. $18 \beta$-GA, however, is known to impair $11 \beta$ HSD2 function by blocking enzymatic activity rather than by inducing down-regulation at the transcriptional level (Zhang et al, 2009; Kratschmar et al, 2011). In view of our recent findings (Cirillo et al, 2012), we tentatively suggest that $18 \beta$-GA may reduce tissue inflammation and limit the bone loss that occurs in periodontal disease by increasing local cortisol levels. Further studies, however, are required to verify this proposal.

Our data demonstrate that silencing of $11 \beta$-HSD1 correlates with a temporary decrease in the local bioavailability of active cortisol, which increases once $11 \beta$-HSD1 expression is restored. The reverse is true for $11 \beta$-HSD2 where expression of the enzyme inversely correlates with cortisol levels. Therefore, alteration of $11 \beta$-HSD $1 / 2$ expression and function is tightly linked to the levels of cortisol in the microenvironment. In the present study, we examined the expression of $11 \beta$-HSD enzymes in a broad spectrum of cancer-types using an open IHC database. We show that dysregulation of $11 \beta$-HSDs is common in a broad spectrum of cancer-types; the enzymes were either upregulated $(11 \beta$-HSD1) or downregulated (11 $\beta$-HSD2), or both, in 11 out of 15 cancer types from 315 cases; the trend was consistent with an increase in the 
bioavailability of local cortisol. In SCC of the skin, there was a significant downregulation of $11 \beta$-HSD2 compared to normal skin., findings that are in accord with results from colorectal (Žbánková et al, 2004) and oral (Cirillo et al, 2012) cancers, but contrast with osteosarcoma (Bland et al, 1999) and ovarian cancer (Temkin et al, 2006). The subject has recently been extensively reviewed (Azher et al, 2016).

Recently, it has been shown that corticosteroids suppress key components of the senescence-associated secretory phenotype (SASP) (Laberge et al, 2012). In epithelial cells, cellular senescence is a mechanism that suppresses the early stages of cancer development suggesting that tumour-derived cortisol may inhibit the anti-cancer activity of the SASP and favour cancer progression. By contrast, we have shown that the SASP of cancer-associated fibroblasts (CAFs) exerts pro-tumourigenic paracrine effects on malignant oral epithelial cells (Lim et al, 2011; Hassona et al, 2013; 2014). In these circumstances, cortisol produced by malignant epithelial cells would be expected to have paracrine tumour suppressive effects. Interestingly, our recent observations have shown that cortisol is produced by normal fibroblasts (Cirillo et al, 2012) as well as cancer-associated fibroblasts (CAFs) (Cirillo N, unpublished observations). Studies are ongoing to investigate the role of cortisol in the tumour micro-environment and the interrelationship between epithelial cells, fibroblasts and immune cells.

In conclusion, we report that a non-adrenal GC system is active in cancer and that the resulting cortisol production suppresses lymphocyte proliferation. Further, we show that $11 \beta$-HSD2 modulates intercellular cohesion and that inhibition of $11 \beta$ HSD2 leads to an increase of secreted cortisol in epidermal cells. $11 \beta$-HSD2 is downregulated in SCCs of the skin as well as in eight other cancer types. We suggest that $11 \beta$-HSD2 could be used as a potential biomarker of tumour progression and may be of value therapeutically by regulating local tissue concentrations of cortisol in skin disease.

\section{ACKNOWLEDGEMENTS}

This study was funded by the Ministero dell'Istruzione, dell'Universita' e della Ricerca, MIUR-PRIN 2008 (NC), a CMM grant from the University of Bristol (NC) and a DDS grant from the University of Melbourne (NC and MJM). The authors gratefully acknowledge the support of the Melbourne Dental School, Victoria, Australia.

\section{CONFLICT OF INTEREST}

The authors declare no conflict of interest.

\section{REFERENCES}

Ahmadi M, Emery DC, Morgan DJ (2008) Prevention of both direct and cross-priming of antitumor CD8 + T-cell responses following overproduction of prostaglandin E2 by tumor cells in vivo. Cancer Res 68: $7520-7529$

Azher S, Azami O, Amato C, McCullough M, Celentano A, Cirillo N (2016) The non-conventional effects of glucocorticoids in cancer. J Cell Physiol 231: 2368-2373.

Basingab FS, Ahmadi M, Morgan DJ (2016) IFN $\gamma$-dependent interactions between ICAM-1 and LFA-1 counteract prostaglandin E2-mediated inhibition of antitumor CTL responses. Cancer Immunol Res 4: 400-411.

Bland R, Worker C, Noble B, Eyre L, Bujalska I, Sheppard M, Stewart P, Hewison M (1999) Characterization of 11beta-hydroxysteroid dehydrogenase activity and corticosteroid receptor expression in human osteosarcoma cell lines. J Endocrinol 161: 455-464.
Boukamp P, Petrussevska RT, Breitkreutz D, Hornung J, Markham A, Fusenig NE (1988) Normal keratinization in a spontaneously immortalized aneuploid human keratinocyte cell line. J Cell Biol 106: 761-771.

Calautti E, Cabodi S, Stein PL, Hatzfeld M, Kedersha N, Dotto PG (1998) Tyrosine phosphorylation and src family kinases control keratinocyte cellcell adhesion. J Cell Biol 141: 1449-1465.

Cirillo N, Boutros S (2008) Fate of desmoglein 3 and E-cadherin in anchorageindependent growth and adhesion to substrates of oral squamous carcinoma cells. J Stomatol Invest 2: 41-51.

Cirillo N, Lanza A, Prime SS (2010) Induction of hyper-adhesion attenuates autoimmune-induced keratinocyte cell-cell detachment and processing of adhesion molecules via mechanisms that involve PKC. Exp Cell Res 316: 580-592.

Cirillo N, Prime SS (2011) Keratinocytes synthesize and activate cortisol. J Cell Biochem 112: 1499-1505.

Cirillo N, Hassona Y, Pignatelli M, Gasparoto TH, Morgan DJ, Prime SS (2012) Characterization of a novel oral glucocorticoid system and its possible role in disease. J Dent Res 91: 97-103.

Cirillo N, Gombos F, Lanza A (2007) Pemphigus vulgaris immunoglobulin G can recognize a 130,000 MW antigen other than desmoglein 3 on peripheral blood mononuclear cell surface. Immunology 121: 377-382.

Cooper MS (2008) 11beta-Hydroxysteroid dehydrogenase: a regulator of glucocorticoid response in osteoporosis. J Endocrinol Invest 31(7S): 16-21.

Davies E, MacKenzie SM (2003) Extra-adrenal production of corticosteroids. Clin Exp Pharmacol Physiol 30(7): 437-445.

Davies M, Paterson IC, Ganapathy A, Prime SS (2006) Cell death induced by $\mathrm{N}$-(4-hydroxyphenyl)retinamide in human epidermal keratinocytes is modulated by TGF-beta and diminishes during the progression of squamous cell carcinoma. Int J Cancer 119: 2803-2811.

Fusenig NE, Boukamp P (1998) Multiple stages and genetic alterations in immortalization, malignant transformation, and tumour progression of human skin keratinocytes. Mol Carcinog 23(3): 144-158.

Hannen RF, Michael AE, Jaulim A, Bhogal R, Burrin JM, Philpott MP (2011) Steroid synthesis by primary human keratinocytes; implications for skin disease. Biochem Biophys Res Commun 404: 62-67.

Hassona Y, Cirillo N, Lim KP, Herman A, Mellone M, Thomas GJ, Pitiyage GN, Parkinson EK, Prime SS (2013) Progression of genotypespecific oral cancer leads to senescence of cancer-associated fibroblasts and is mediated by oxidative stress and TGF- $\beta$. Carcinogenesis 34: 1286-1295.

Hassona Y, Cirillo N, Heesom K, Parkinson EK, Prime SS (2014) Senescent cancer-associated fibroblasts secrete active MMP-2 that promotes keratinocyte dis-cohesion and invasion. Br J Cancer 111: 1230-1237.

Hardy RS, Filer A, Cooper MS, Parsonage G, Raza K, Hardie DL, Rabbitt EH, Stewart PM, Buckley CD, Hewison M (2006) Differential expression, function and response to inflammatory stimuli of 11beta-hydroxysteroid dehydrogenase type 1 in human fibroblasts: a mechanism for tissuespecific regulation of inflammation. Arthritis Res Ther 8: R108.

Hennebert O, Chalbot S, Alran S, Morfin R (2007) Dehydroepiandrosterone 7alpha hydroxylation in human tissues: possible interference with type 1 11 betahydroxysteroid dehydrogenase-mediated processes. J. Steroid Biochem Mol Biol 104: 326-333.

Herr I, Pfitzenmaier J (2006) Glucocorticoid use in prostate cancer and other solid tumours: implications for effectiveness of cytotoxic treatment and metastases. Lancet Oncol 7: 425-430.

Itoi S, Terao M, Murota H, Katayama I (2013) 11 $\beta$-Hydroxysteroid dehydrogenase 1 contributes to the pro-inflammatory response of keratinocytes. Biochem Biophys Res Commun 440: 265-270.

Jackson S, Gilchrist H, Nesbitt Jr LT (2007) Update on the dermatologic use of systemic glucocorticosteroids. Dermatol Ther 20: 187-205.

Janicki CN, Jenkinson SR, Williams NA, Morgan DJ (2008) Loss of CTL function amongst high avidity tumor-specific CD8+ T cells following tumor infiltration. Cancer Research 68(8): 2993-3000.

Jenkinson SR, Williams NA, Morgan DJ (2005) The role of intercellular adhesion molecule-1/LFA-1 interactions in the generation of tumorspecific CD8+ T cell responses. J Immunol 174(6): 3401-3407.

Laberge RM, Zhou L, Sarantos MR, Rodier F, Freund A, de Keizer PL, Liu S, Demaria M, Cong YS, Kapahi P, Desprez PY, Hughes RE, Campisi J (2012) Glucocorticoids suppress selected components of the senescenceassociated secretory phenotype. Aging Cell 11: 569-578.

Lanza A, Cirillo N, Rossiello R, Rienzo M, Cutillo L, Casamassimi A, de Nigris F, Schiano C, Rossiello L, Femiano F, Gombos F, Napoli C (2008) Evidence of key role of Cdk2 overexpression in pemphigus vulgaris. J Biol Chem 283: 8736-8745. 
Lee SE, Kim JM, Jeong MK, Zouboulis CC, Lee SH (2013) 11 $\beta$-hydroxysteroid dehydrogenase type 1 is expressed in human sebaceous glands and regulates glucocorticoid-induced lipid synthesis and toll-like receptor 2 expression in SZ95 sebocytes. Br J Dermatol 168: 47-55.

Lim KP, Cirillo N, Hassona Y, Wei W, Thurlow JK, Cheong SC, Pitiyage G, Parkinson EK, Prime SS (2011) Fibroblast gene expression profile reflects the stage of tumour progression in oral squamous cell carcinoma. J Pathol 223: 459-469.

Kantak SS, Kramer RH (1998) E-cadherin regulates anchorage-independent growth and survival in oral squamous cell carcinoma cells. J Biol Chem 273: 16953-16961.

Kennedy D, Pignatelli M, Hassona Y, Prime SS, Cirillo N (2015) The role of the glucocorticoid system in anchorage-independence during progression of squamous cell carcinoma. Am J Oral Med 1: 8-19.

Knutson KL, Disis ML (2005) Tumor antigen-specific T helper cells in cancer immunity and immunotherapy. Cancer Immunol Immunother 54: 721-728.

Kratschmar DV, Vuorinen A, Da Cunha T, Wolber G, Classen-Houben D, Doblhoff O, Schuster D, Odermatt A (2011) Characterization of activity and binding mode of glycyrrhetinic acid derivatives inhibiting $11 \beta$ hydroxysteroid dehydrogenase type 2. J Steroid Biochem Mol Biol 125: 129-142.

Ma X, Lian QQ, Dong Q, Ge RS (2011) Environmental inhibitors of 11 $\beta$-hydroxysteroid dehydrogenase type 2. Toxicology 285: 83-89.

MacKenzie SM, Clark CJ, Fraser R, Gómez-Sánchez CE, Connell JM, Davies E (2000) Expression of 11beta-hydroxylase and aldosterone synthase genes in the rat brain. J Mol Endocrinol 24(3): 321-328.

Milewich L, Shaw CB, Sontheimer RD (1988) Steroid metabolism by epidermal keratinocytes. Ann NY Acad Sci 548: 66-89.

Nakata T, Fujita A, Umeda M, Yoshida H, Inami K, Masuzaki H, Sawai H (2016) The increased ratio of $11 \beta$-hydroxysteroid dehydrogenase type 1 versus $11 \beta$-hydroxysteroid dehydrogenase type 2 in chronic periodontitis irrespective of obesity. Springerplus 16: 5-40.

Nguyen VT, Arredondo J, Chernyavsky AI, Kitajima Y, Pittelkow M, Grando SA (2004) Pemphigus vulgaris IgG and methylprednisolone exhibit reciprocal effects on keratinocytes. J Biol Chem 279: 2135-2146.

Noti M, Sidler D, Brunner T (2009) Extra-adrenal glucocorticoid synthesis in the intestinal epithelium: more than a drop in the ocean? Semin Immunopathol 31: 237-248.

Purnell JQ, Kahn SE, Samuels MH, Brandon D, Loriaux DL, Brunzell JD (2009) Enhanced cortisol production rates, free cortisol, and 11beta-HSD1 expression correlate with visceral fat and insulin resistance in men: effect of weight loss. Am J Physiol Endocrinol Metab 296: E351-E357.

Rabbitt EH, Gittoes NJ, Stewart PM, Hewison M (2003) 11betahydroxysteroid dehydrogenases, cell proliferation and malignancy. J Steroid Biochem Mol Biol 85: 415-421.

Ricketts ML, Verhaeg JM, Bujalska I, Howie AJ, Rainey WE, Stewart PM (1998) Immunohistochemical localization of type 111 beta-hydroxysteroid dehydrogenase in human tissues. J Clin Endocrinol Metab 83: 1325-1335.

Sapolsky RM, Romero LM, Munck AU (2000) How do glucocorticoids influence stress responses? Integrating permissive, suppressive, stimulatory, and preparative actions. Endocr Rev 21(1): 55-89.

Sasaki H, Suzuki N, Alshwaimi E, Xu Y, Battaglino R, Morse L, Stashenko P (2010) $18 \beta$-glycyrrhetinic acid inhibits periodontitis via glucocorticoidindependent nuclear factor- $\mathrm{\kappa B}$ inactivation in interleukin-10-deficient mice. J Periodontal Res 45: 757-763.

Sidler D, Renzulli P, Schnoz C, Berger B, Schneider-Jakob S, Flück C, Inderbitzin D, Corazza N, Candinas D, Brunner T (2011) Colon cancer cells produce immunoregulatory glucocorticoids. Oncogene 30: 2411-2419.

Slominski A, Zbytek B, Pisarchik A, Slominski RM, Zmijewski MA, Wortsman J (2006) CRH functions as a growth factor/cytokine in the skin. J Cell Physiol 206: 780-791.

Slominski A, Wortsman J, Tuckey RC, Paus R (2007) Differential expression of HPA axis homolog in the skin. Mol Cell Endocrinol 266: 143-149.
Slominski AT, Zmijewski MA, Zbytek B, Brozyna AA, Granese J, Pisarchik A, Szczesniewski A, Tobin DJ (2011) Regulated proenkephalin expression in human skin and cultured skin cells. J Invest Dermatol 131: 613-622.

Slominski A, Wortsman J (2000) Neuroendocrinology of the skin. Endocr Rev 21: 457-487.

Slominski A, Gomez-Sanchez CE, Foecking MF, Wortsman J (2000) Active steroidogenesis in the normal rat skin. Biochim Biophys Acta 1474: 1-4.

Takeda Y, Miyamori I, Yoneda T, Iki K, Hatakeyama H, Takeda R (1994) Effect of aging on urinary excretion of 18-hydroxycortisol. J Steroid Biochem Mol Biol 50(3-4): 167-168.

Terao M, Murota H, Kimura A, Kato A, Ishikawa A, Igawa K, Miyoshi E, Katayama I (2011) 11 $\beta$-Hydroxysteroid dehydrogenase-1 is a novel regulator of skin homeostasis and a candidate target for promoting tissue repair. PLoS One 6: e25039.

Terao M, Itoi S, Murota H, Katayama I (2013) Expression profiles of cortisolinactivating enzyme, $11 \beta$-hydroxysteroid dehydrogenase-2, in human epidermal tumors and its role in keratinocyte proliferation. Exp Dermatol 22: 98-101.

Terao M, Tani M, Itoi S, Yoshimura T, Hamasaki T, Murota H, Katayama I (2014) $11 \beta$-hydroxysteroid dehydrogenase 1 specific inhibitor increased dermal collagen content and promotes fibroblast proliferation. PLoS One 25: e93051.

Temkin S, Nacharaju VL, Hellman M, Lee Y-C, Abulafia O (2006) Type 2 $11 \beta$-hydroxysteroid dehydrogenase activity in human ovarian cancer. Steroids 71: 1019-1023.

Tiganescu A, Walker EA, Hardy RS, Mayes AE, Stewart PM (2011) Localization, age- and site-dependent expression, and regulation of $11 \beta$-hydroxysteroid dehydrogenase type 1 in skin. J Invest Dermatol 131: $30-36$.

Tiganescu A, Hupe M, Jiang YJ, Celli A, Uchida Y, Mauro TM, Bikle DD, Elias PM, Holleran WM (2015) UVB induces epidermal $11 \beta$ hydroxysteroid dehydrogenase type 1 activity in vivo. Exp Dermatol 24: 370-376.

Tomlinson JW, Walker EA, Bujalska IJ, Draper N, Lavery GG, Cooper MS, Hewison M, Stewart PM (2004) 11beta-hydroxysteroid dehydrogenase type 1: a tissue-specific regulator of glucocorticoid response. Endocr Rev 25: 831-866.

Vacchio MS, Papadopoulos V, Ashwell JD (1994) Steroid production in the thymus: implications for thymocyte selection. J Exp Med 179: 1835-1846.

Vukelic S, Stojadinovic O, Pastar I, Rabach M, Krzyzanowska A, Lebrun E, Davis SC, Resnik S, Brem H, Tomic-Canic M (2011) Cortisol synthesis in epidermis is induced by IL-1 and tissue injury. J Biol Chem 286: 10265-10275.

Ward MJ, Thirdborough SM, Mellows T, Riley C, Harris S, Suchak K, Webb A, Hampton C, Patel NN, Randall CJ, Cox HJ, Jogai S, Primrose J, Piper K, Ottensmeier CH, King EV, Thomas GJ (2014) Tumourinfiltrating lymphocytes predict for outcome in HPV-positive oropharyngeal cancer. Br J Cancer 110: 489-500.

Yao Y, Pan Y, Chen J, Sun X, Qiu Y, Ding Y (2007) Endoglin (CD105) expression in angiogenesis of primary hepatocellular carcinomas: analysis using tissue microarrays and comparisons with CD34 and VEGF. Ann Clin Lab Sci 37: 39-48.

Žbánková Š, Bryndová J, Kment M, Pácha J (2004) Expression of 11 $\beta$ hydroxysteroid dehydrogenase types 1 and 2 in colorectal cancer. Cancer Lett 210: 95-100.

Zhang MZ, Xu J, Yao B, Yin H, Cai Q, Shrubsole MJ, Chen X, Kon V, Zheng W, Pozzi A, Harris RC (2009) Inhibition of 11beta-hydroxysteroid dehydrogenase type II selectively blocks the tumor COX-2 pathway and suppresses colon carcinogenesis in mice and humans. J Clin Invest 119: 876-885.

This work is published under the standard license to publish agreement. After 12 months the work will become freely available and the license terms will switch to a Creative Commons AttributionNonCommercial-Share Alike 4.0 Unported License.

Supplementary Information accompanies this paper on British Journal of Cancer website (http://www.nature.com/bjc) 